\title{
KONKURAVIMO STRATEGIJŲ POVEIKIS EKSPORTO MARKETINGO STRATEGIJAI IR IMONĖS EKSPORTO VEIKLOS REZULTATAMS
}

\author{
Regina Virvilaité ${ }^{1}$, Beata Šeinauskiené ${ }^{2}$ \\ ${ }^{1}$ Kauno technologijos universitetas, Lietuva, regina.virvilaite@ktu.lt \\ ${ }^{2}$ Kauno technologijos universitetas, Lietuva, beata.seinauskiene@ktu.lt \\ crossref $\mathrm{http} / / \mathrm{dx}$.doi.org/10.5755/j01.em.17.3.2133
}

\begin{abstract}
Studies investigating the relationship of export marketing strategy standardization/adaptation and firm export performance recently emphasize the importance of internal factors. According to Schilke et al (2009) standardization must be explored in the relationship with the other relevant firm's strategies that may have significant implications for the effect of standardization on performance. Schilke et al (2009) found that standardization is more important to performance when a cost leadership strategy is pursued. The findings of other studies (Aulakh et al, 2000) revealed that a cost leadership strategy has a stronger effect on export performance in developed country markets and that firms using a standardized approach in developed countries have lower performance than those adapting their marketing strategies. Other studies (Solberg, Durrieu, 2008) did not provided the empirical support for the existence of direct or indirect impact of competitive strategies through standardization on firm performance. Existing findings provide only limited and mixed results and controversy remains regarding the impact of competitive strategies on the relationship of standardization/adaptation and performance. The aim of the article - theoretically substantiate the conceptual framework depicting the link between the competitive strategies, export marketing strategy standardization/adaptation and export performance.

Keywords: export marketing strategy, standardization, adaptation, competitive strategy, export performance.

JEL Classification: M31, M16, M21.
\end{abstract}

\section{Ivadas}

Mokslinejje literatūroje nèra vieningos nuomonès dèl bendrujų konkuravimo strategijų ir eksporto marketingo strategiju (standartizacijos/adaptacijos) sąsaju bei jų jungtinio poveikio imonès veiklos rezultatams. Vieni mokslininkai teigia, kad ryšys tarp bendrujų konkuravimo strategijų ir imonès veiklos rezultatu yra netiesioginis, isiterpiant eksporto marketingo strategijoms (Solberg, Durrieu, 2008), kiti autoriai (Schilke, Reimann ir Thomas, 2009) mano, kad tarptautinès marketingo strategijos (eksporto marketingo strategija taip pat priskirtina prie tarptautinių marketingo strategijų, taikomų pradiniame imonių internacionalizacijos etape naudojant eksporto i̇ejjimo i̇ užsienio rinką metodą) efektyvumas priklauso nuo i̇monès plètojamos konkuravimo strategijos, daroma prielaida, kad geresnius i̇monès veiklos rezultatus sąlygoja minètų strategijų suderinamumas. Shilke et al (2009) teigimu, bendrosios konkuravimo strategijos laikytinos reikšmingu moderuojančiu veiksniu. Minètų autorių manymu, diferenciacijos strategiją taikančių imonių atveju, kuomet siektinas tikslas yra prekès ar paslaugos unikalumas, standartizacijos strategijos teikiama nauda yra santykinai mažesnè nei ji būtu taikant adaptaciją, taigi, esant minètai situacijai, standartizacija nelaikytina reikšmingu i̇monès veiklos rezultatu determinantu. Ir priešingai, diferenciacijos strategiją taikančioms imonèms tikètina reikès adaptuoti savo marketingo programas ir pritaikyti savo pasiūlymus siekiant diferenciacija grindžiamo konkurencinio pranašumo, kadangi diferenciacijos strategijos atveju, svarbiausias i̇monių tikslas - kuo geriau patenkinti skirtingus vartotojų norus ir poreikius.

Pažymėtina, jog skirtingos įvairių autorių konkuravimo strategijų ir tarptautinių marketingo strategijų teorinès konceptualizacijos dar labiau apsunkina sąsajų tarp šių konstruktų analizę. Kaip pavyzdžiui, Baldauf, Cravens ir Wagner (2000) kaštų lyderystès strategiją prilygina standartizacijos, o diferenciacijos strategija - adaptacijos strategijai, tvirtinant, kad jos panašios. Tuo tarpu Aulakh, Kotabe ir Teegen (2000) pažymi, kad marketingo standartizacija skiriasi nuo kaštu lyderystės ir diferenciacijos. Bendrosios konkuravimo strategijos atskleidžia imonès poziciją/laikyseną konkurentų atžvilgiu, tuo tarpu marketingo standartizacija susijusi su marketingo programų ir procesų tarp vidaus ir užsienio šaliu rinkų arba tarp daugelio užsienio šalių rinkų suderinamumu. Taigi, autorių nuomone, tiek kaštų lyderyste, tiek diferenciacija grindžiamas konkurencines strategijas taikančios imonès gali igyvendinti arba standartizuotas, arba adaptuotas marketingo programas. Eksportuojanti imoné, kurios konkurencinis pranašumas grindžiamas diferenciacija, gali pasitelkti panašias arba skirtingas diferenciacijos akcentavimo priemones skirtingose užsienio šaliu rinkose. Vienoje šalyje įmonès prekè gali būti diferencijuojama kaip prestižinè prekè, taikant premijines kainas ir parduodant prabangos parduotuvėse. Kitoje šalyje tos pačios prekès diferenciacijos 
šaltiniu gali būti paslaugos, pasirenkant jau kitus paskirstymo kanalus. Taigi, Aulakh et al (2000) manymu, eksportuotojas, nors ir taikantis diferenciacijos strategiją abiejose rinkose, marketingo programą adaptuoja atsižvelgiant $\mathfrak{i}$ kiekvienos užsienio rinkos specifiką. Kitų mokslinių tyrimų rezultatai implikuoja, kad ypač entrepreneriškos, i̇ augimą orientuotos i̇monès, kurių konkurencinis pranašumas grindžiamas diferenciacija, tarptautinëje rinkoje prioritetą teikia adaptacijai (Hagen, Zucchella, Cerchiello, Giovanni, 2011).

Mokslinès literatūros analizė leidžia konstatuoti, kad tyrimai bendrujų konkuravimo strategijų bei eksporto marketingo strategijų poveikio eksporto veiklos rezultatams atžvilgiu yra fragmentiški, prieštaringi, tik keletas mokslininkų analizavo empiriškai ir parodè ryšius tarp minètų konstruktų (Aulakh, Kotabe, Teegen 2000; Schilke, Reimann, Thomas, 2009; Solberg, Durrieu, 2008). Siekiant užpildyti moksliniu tyrimų atotrūki tikslinga tirti, kokị poveikį eksporto marketingo strategija daro įmonès eksporto veiklos rezultatams, atsižvelgiant į i̇monès bendrąsias konkuravimo strategijas. Mokslinè problema šiame straipsnyje formuluojama klausimu: Kaip bendrosios konkuravimo strategijos veikia ryši tarp eksporto marketingo strategijos standartizacijos/adaptacijos ir eksporto veiklos rezultatu?

Straipsnio tikslas - parengti sąsajų tarp bendrujų konkuravimo strategijų eksporto marketingo strategijos standartizacijos/adaptacijos ir eksporto veiklos rezultatų konceptualų modeli.

Tyrimo metodai - lyginamoji ir sisteminè mokslinès literatūros analizè.

\section{Bendrosios konkuravimo strategijos ir jų poveikis įmonės veiklos rezultatams}

Porter (1980) bendrosios konkuravimo strategijos parodo kaip įmonès, atsižvelgiant ị konkurentus sukuria vartotojams vertę. Bendruju konkuravimo strategiju tipologijos atveju akcentuojama išoriniu veiksnių, tokių kaip vartotojai ir konkurentai, svarba, konkuravimo strategiją apibūdinant kaip palankios konkurencinès pozicijos pramonès sektoriuje, paiešką. Kaštų lyderystės ir diferenciacijos strategijos rodo, kaip i̇monės plètoja savo pranašumus prieš konkurentus pramonès šakoje. Taigi, bendrosios konkuravimo strategijos atskleidžia, kaip įmonès igyja konkurencini pranašumą - siekiant vartotojų suvokiamo pranašumo kaštuose arba prekejje ir kaip šie pranašumai panaudojami skirtingose tikslinèse rinkose - esant plačiai rinkos aprèpčiai ar koncentruojantis i nišas.

Diferenciacijos strategija parodo, kokiu būdu imonès siekia išskirti savo prekes iš konkuruojančiu pasiūlymų. Diferenciacijos požiūris sietinas su vartotojų teigiamai vertinamo išskirtinumo konkurentų atžvilgiu sukūrimu, pasiūlant didesnę vertę suteikiamos informacijos, prestižo, priimtinesniu paskirstymo kanalų forma (Schilke, Reimann ir Thomas, 2009). Industrinès organizacijos ekonomistai dažnai diferenciaciją apibūdina kaip būdą konkurencijai sumažinti (Chamberlin, 1933), kadangi diferenciacijos

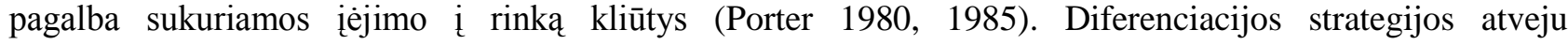
konkurencinis pranašumas grindžiamas išskirtinumu konkurentu atžvilgiu ir geresniu vartotojų poreikiu tenkinimu, kas galiausiai sudaro prielaidas imonėms taikyti premijines kainas (Schilke, Reimann ir Thomas, 2009). Diferenciacijos strategija - tai pastangos sukurti vartotojo požiūriu unikalią vertę, igalinančią i̇monę padidinti vartotojų lojalumą bei taikyti premijines kainas, kompensuojančias papildomus su šia strategija susijusius kaštus (Myers, Harvey 2001; Porter 1985). Diferenciacijos strategijos taikymo galimybes riboja ¿̇monès disponuojami ištekliai, taigi diferenciacijos strategijos plètojimas neatsiejamas nuo imonès disponuojamų unikalių bei specifinių išteklių. Dažniausiai ištekliais grịstu požiūriu (angl. resource based view, RBV) besiremiančioje mokslinèje literatūroje minimi tokie ekonominę rentą generuojantys unikalūs arba specializuoti ištekliai kaip prekiu ženklai, sukauptos technologinės žinios, kvalifikuotas personalas (Mosakowski, 1993). Būtent pastarieji diferenciacijos šaltiniai dažniausiai pasitelkiami diferencijuojant imonès prekes. Aulakh et al (2000) teigimu, diferenciacijos strategiją taikančios ímonès siekia sukurti vartotoju požiūriu unikalią prekę ar paslaugą. Pasiūlymo unikalumas gali būti grindžiamas teigiamu prekès ženklo įvaizdžiu, išskirtine technologija, paslaugomis ar inovatyviais produktais. Diferenciacijos strategija taikančių imonių tikslas - padidinti vartotojų lojalumą ir sukurti iẻjimo kliūtis naujiems rinkos žaidèjams. Dèl lojalumo prekės ženklui sumažèjęs paklausos, kainos atžvilgiu, elastingumas sąlygoja didesnes pelno maržas.

Kaštų lyderystès strategijos atveju siekiama už mažesnę kainą vartotojui suteikti tą pačią ar didesnę vertę. Siekiant kaštų pranašumo daug dèmesio skiriama vidinių procesų optimizavimui, laikomasi griežtos politikos kaštų mažinimo per sukauptą gamybos patirti, pridètinių išlaidų kontrolès atžvilgiu, tikslingai minimizuojami kaštai tokiuose vertès grandinès etapuose kaip tyrimai ir plètra, paslaugos, pardavimų pajėgos, reklama (Porter, 1980). Dẻka šios strategijos gaunama didesnė nei vidutinè grąža, kadangi įmonès net ir sumažinę kainą iki konkurentų kainų lygmens, vis dar uždirba pelną. Kaštų lyderystės strategijos atveju imonėms pavyksta išlaikyti konkurencini pranašumą dèl kaštų struktūros, taigi, jos gali pasiūlyti žemiausias 
kainas savo vartotojams. Dėl šio konkurencinio pranašumo, imonės gamybos ir pardavimų apimtys yra didesnès lyginant su konkurentais. Taigi, i̇monès pasiekia didesnę masto ekonomiją nei jų konkurentai, kas dar labiau sustiprina jų kaip kaštų lyderiu pozicijas rinkoje (Grant, 1998; Hitt, Ireland, Hoskisson 2001). Kaštų lyderystės pranašumo šaltiniais įvardijami tiek masto ekonomika, tiek ir patirties/mokymosi kreivė (Makadok, 1999).

Diferenciacijos strategijos atveju rinkos dalis paprastai yra mažesnè nei kaštu lyderystès atveju, tačiau ilgajame periode abi strategijos leidžia pasiekti tą pati pelno lygi (Baldauf, Cravens, Wagner, 2000). Taigi, ryšys tarp diferenciacijos ir eksporto efektyvumo, taip pat kaip ir tarp kaštu lyderystès ir eksporto efektyvumo yra teigiamas. Vis tik diferenciacijos strategija Baldauf et al (2000) manymu, turètu salygoti mažesni eksporto intensyvumą ir mažesnes eksporto pardavimų apimtis, kadangi taikant šią strategiją paprastai aptarnaujamas mažesnis klientų skaičius nei kaštu lyderystės atveju. Tačiau empirinio tyrimo rezultatai leido patvirtinti ne visas minètų autorių prielaidas. Priešingai nei prognozuota buvo konstatuotas neigiamas ryšys tarp žemų kaštu strategijų ir eksporto efektyvumo, o ryšys tarp žemų kaštų strategijų ir eksporto intensyvumo bei eksporto pardavimo apimčių pasirode esąs statistiškai nereikšmingas.

Li ir Li (2008) teigimu, nepaisant plačiai pripažistamos bendrujų konkuravimo strategiju paaiškinamosios vertès, iki šiol nèra bendro sutarimo dèl šių strategijų poveikio i̇monių veiklos rezultatams. Pagrindiniu diskusiniu klausimu išlieka svarstymai, ar šie požiūriai yra abipusiai suderinami, kurių strategiju atveju, grynujų, kuomet taikoma tik kaštų lyderystės arba tik diferenciacijos strategija, ar dvigubų, esant kaštu lyderystès ir diferenciacijos deriniui, pasiekiami geresni imonès veiklos rezultatai. Bendruju konkuravimo strategijų ir ju poveikio imonès veiklos rezultatams empiriniai tyrimai yra prieštaringi. Pramoninių prekių gamintojų atveju tyrimo rezultatai patvirtino, kad išimtinai vienos kurios konkuravimo strategijos taikymas siejamas su geresniais imonès veiklos rezultatais (Dess, Davis, 1984). Kitu empiriniu tyrimu rezultatai parodè, kad ilgajame periode kaštu minimizavimo ir diferenciacijos derinimo atveju pasiekiami geresni veiklos rezultatai nei orientuojantis tik į kurią nors vieną konkuravimo strategiją (Buzell, Gale, 1987; Murray, 1988; Parnell, Wright, 1993). Taip pat mokslinèje literatūroje sutinkama ir tvirtinimų, kad diferenciacija gali sąlygoti kaštų efektyvumą (Jones, Butler, 1988). Anot Solberg ir Durieu (2008) tokios prielaidos grindžiamos spartejančios globalizacijos sąlygotais rinkų ir konkurencijos pokyčiais. Tokie reiškiniai kaip lankstesnès gamybinès sistemos, galimybės sumažinti kaštus paslaugu nuomos būdu, virtualios organizacijos iš esmès keičia žemų kaštų, masto ekonomijos konkurencini pranašumą, konkuravimo strategijų derinimas tampa tinkamesniu pasirinkimu.

Porter (1985) isitikinimu, abiejų konkuravimo strategijų taikymas vienu metu traktuotinas kaip neracionalus sprendimas, kadangi dèl iš esmès skirtingu požiūrių konkurencinio pranašumo sukūrimo ir išlaikymo atžvilgiu, kiekvienos strategijos atveju didesnę reikšmę igauna vis kiti ištekliai, i̇monès stiprybès ar organizacinės priemonės. Grynujų konkuravimo strategijų šalininkų teigimu, norint sėkmingai veikti, imonès turi pasirinkti ir susikoncentruoti tik $\mathfrak{i}$ vienos kurios grynosios konkuravimo strategijos taikymą, nes priešingu atveju įmonė rizikuoja įstrigti neperspektyviame „viduryje”. Tačiau kiti mokslininkai teigia, kad priešingai i̇sivyravusiai nuostatai, minèti požiūriai nèra nesuderinami $(\mathrm{Li}, \mathrm{Li}, 2008)$. Dviguba strategija tuo pat metu akcentuojant ir kaštų lyderystę ir diferenciaciją, leidžia pasiekti geresnius įmonès veiklos rezultatus lyginant su konkurentais (Beal ir Yasai-Ardekani 2000). Naujausios mokslinès ižžalgos rodo, kad bendrujų konkuravimo strategijų veiksmingumas jų poveikio imonès veiklos rezultatams atžvilgiu priklauso nuo strategijų suderinamumo su įvairiais kontekstiniais veiksniais, kaip pavyzdžiui pramonès šakos brandos lygio (Louri, Anagnostaki, 1995) ir rinkos dinamiškumo (Parker and Helms 1992). Murray (1988) teigimu, kaštu lyderystès strategijos praranda savo veiksmingumą brandžiose pramonès šakose, tačiau yra veiksmingos esant stabiliai aplinkai kai tuo tarpu diferenciacijos strategijos veiksmingesnès esant didesniam aplinkos neapibrezžtumui (Miller, 1988; Ward, Bickford, Leong, 1996). Taip pat teigiama, kad brandžiose rinkose labiau pasiteisina dvigubos strategijos (Hill,1988). Dvigubos strategijos sietinos ir su gerais veiklos rezultatais pramonès šakos gyvavimo ciklo nuosmukio etape (Parker, Helms, 1992). Hall (1980) teigimu, derinant diferenciaciją ir kaštų lyderystę imonès veikla nepažystamoje aplinkoje paprastai yra sèkmingesnè.

Kintančioje globalioje aplinkoje lankstūs strateginiai deriniai leidžia lengviau prisitaikyti prie dinamiškos globalios rinkos. Empirinių tyrimų rezultatai rodo, kad skirtingų konkuravimo strategijų derinys esant tam tikroms aplinkybėms garantuoja i̇monėms sėkmę (Li, Li, 2008). Daugelio mokslininkų nuomone, kaštų lyderystès, diferenciacijos ar dvigubos strategijos efektyvumas turètų priklausyti nuo konteksto, aplinkos, kurioje šios strategijos igyvendinamos. Li ir Li (2008) manymu, kaštų lyderystès, diferenciacijos ir dvigubos strategijos daro skirtinga poveiki finansiniams šalies vidaus rinkoje ir užsienio šaliu rinkose veikiančių imonių rezultatams, bei bendrujų konkuravimo strategijų poveikis įmonès veiklos rezultatams gali 
kisti priklausomai nuo rinkos koncentracijos laipsnio. Minètu autoriu ( $\mathrm{Li}, \mathrm{Li}, 2008$ ) manymu dvigubos strategijos teigiamas poveikis įmonès veiklos rezultatams užsienio kilmès imoniu (importuojančiu i̇monių) atveju yra stipresnis lyginant su įmonėmis, kuriu veikla orientuota tik į šalies vidaus rinką. Akivaizdu, kad abi bendrosios konkuravimo strategijos savo esme kildinamos iš skirtingų organizacinių filosofijų (Rust, Moorman, Dickson 2002), taigi, siekiant jų suderinamumo dažnai susiduriama su organizaciniais ir ištekliu konfigūravimo iššūkiais. Nepakankama vadybinė kompetencija ar riboti ištekliai apsunkina galimu suderinamumo konfliktų sprendima, vienu metu igyvendinant strategijas kuriomis siekiama tiek maksimizuoti vartotojų pasitenkinimą, tiek ir minimizuoti kaštus. Sėkmingo skirtingų konkuravimo strategijų lygiagretaus igyvendinimo prielaidos grindžiamos gebëjimu apjungti skirtingas strategines perspektyvas, žiniomis, vadovų funkcinèmis kompetencijomis, patirtimi (Li, Li, 2008).

Tarptautinės įmonės paprastai disponuoja pakankamu išteklių kiekiu ir turi atitinkamas kompetencijas, kad galètų sèkmingai suderinti i i skirtingus tikslus orientuotas konkuravimo strategijas, integruojant tiek efektyvumu gristą pranašumą, igyjamą veiklos operaciju rutinizavimo ir formalizavimo dẻka, tiek diferenciacija grindžiamą pranašumą, pasiekiamą dèka nuolatinių su preke susijusių inovacijų.

Industrinès ekonomikos teorija teigia, kad ryši tarp verslo vienetu strategijų ir jų veiklos rezultatu sustiprina rinkos struktūra (Scherer, Ross, 1990). Siekiant geresniu imonès veiklos rezultatų tiek vidaus, tiek užsienio įmonès turi suderinti savo marketingo strategijas su rinkos struktūros veiksniais. Tarp kitų išorinès aplinkos reikšmingų veiksnių išskiriama rinkos koncentracija. Moksliniuose darbuose rinkos koncentracija dažniausiai suprantama kaip i̇monių rinkoje užimamų didžiausių dalių kombinacija. Kuo mažiau įmonių ir kuo labiau skiriasi jų dydis, tuo rinka labiau koncentruota, o tai reiškia - mažiau konkurencinė (Dumčiuvienè, 1999). Kuo mažesnę dali rinkoje užima stambiausios imonès, tuo konkurencijos intensyvumas rinkoje didesnis. Didesnè rinkos koncentracija signalizuoja rinką igyjant oligopolinius bruožus.

Li ir Li (2008) teigia, kad konkuravimo strategijų ir įmonės veiklos rezultatų ryšys sparčiai augančios ekonomikos šaliu kontekste mažai tyrinètas, o išsivysčiusios ekonomikos šalių atveju egzistuojantys mokslinių tyrimų rezultatai bendrujų konkuravimo strategijų vaidmens ir aplinkos veiksniu itakos atžvilgiu yra prieštaringi. Li ir Li (2008) empirinio tyrimo rezultatai patvirtino ankstesnes mokslininkų ižvalgas jog silpniau ekonomiškai išsivysčiusiose šalyse plètoti dvigubą strategiją palankiau užsienio kilmès i̇monèms nei nacionalinėms imonėms. Minètų autorių tyrimas atskleidè, kad dèl ribotų ištekliu ir nepakankamos vadybinès kompetencijos Kinijos imonės, veikiančios šalies vidaus rinkoje, susiduria su problemomis derindamos prieštaringus aukštos kokybės ir žemų kaštų strateginius tikslus. Tuo tarpu užsienio šalių kilmès ¿monių taikomos dvigubos strategijos yra veiksmingesnès, kadangi šio tipo įmonès turi pakankamai ištekliu ir kompetencijų, kad galètų subalansuoti efektyvumu grịstą plètrą ir kokybe paremtas inovacijas. Taip pat autorių tyrimas atskleide, kad rinkos koncentracijos veiksnys moderuoja bendrujų konkuravimo strategiju poveiki i̇monès veiklos rezultatams. Esant žemam rinkos koncentracijos lygiui kaštų lyderystės teigiamas poveikis susilpnèja. Autoriu manymu, tokie rezultatai implikuoja, jog yra realus pavojus prarasti konkurencini pranašumą plètojant kaštų lyderystès strategiją mažiau koncentruotose rinkose, kurioms būdingas didelis mažų konkuruojančių imonių skaičius ir oportunistinè elgsena. Li ir Li (2008) tyrimu rezultatai taip pat atskleidè, kad diferenciacijos strategija sąlygos tuo geresnius imonès finansinès veiklos rezultatus, kuo mažesnis bus rinkos koncentracijos lygis, patvirtinant egzistuojančias teorines nuostatas, kad kokybe, inovacijomis ar prekès ženklu grịstas diferenciacijos konkurencinis pranašumas gali padèti įmonėms atlaikyti rinkos struktūros sąlygotą spaudimą ir pasiekti geresnių finansinių veiklos rezultatų.

Tarp kitu reikšmingų aplinkybių moksliniuose darbuose minimas ir imoniu iẻjimo i užsienio šalių rinką eiliškumas. Coeurderoy ir Durand (2004) teigimu, nors kaštų lyderyste daro teigiamą poveiki imonès užimamai rinkos daliai, dèl specifiniu ịejjimo į rinką kaštų ir rizikos susijusios su įmonių pionierių inovatyvia strategija bei galimo pasekejju greitos ir lengvos veiklos modelio imitacijos, imonių sekèju iejjimas i naujas rinkas yra efektyvesnis nei imonių pionierių atveju. Vẻliau iz rinką i̇einančios i̇monès turi galimybę pasimokyti iš i̇moniu pionierių klaidų, išvengdamos didesnių su iejjimu i naują rinką susijusių investicijų. Tikètina, kad imonès pasekejjos greičiau pasiveja imones pionieres, kai konkurencinè strategija grindžiama kaštų pranašumu nei tuo atveju, jei įmonių iejjimo strategija būtų siejama su technologinèmis ar marketingo inovacijomis (Porter, 1996; Durand, Coeurderoy, 2001). Taigi, kaštų lyderystès strategiją taikančiu i̇monių ankstyvas iejjimas i naują rinką negarantuoja pastarosioms didesnès rinkos dalies, kadangi pasekèjai gali daugiau išlošti taikydami kaštų lyderystès strategiją. Coeurderoy ir Durand (2004) manymu, kaštų lyderystès strategija yra mažiau palanki i̇monėms pionierèms ir ankstyviesiems pasekèjams, nei vèliau i rinką įeinančioms įmonèms. 
Tarp bendrujų konkuravimo strategiju ir imonès veiklos rezultatų ryšys yra sudètingas (Solberg, Durieu, 2008). Nors mokslinèje literatūroje sutartinai pripažistama, kad bendrosios konkuravimo strategijos yra esminis geru imonès finansiniu veiklos rezultatu šaltinis tiek išsivysčiusios pramonès rinkose, tiek ir augančios ekonomikos šalyse, tačiau Coeurderoy ir Durand (2004) teigimu mokslininkų nuomonès dèl grynujų ir dvigubų strategijų veiksmingumo nesutampa, o atliktų empirinių tyrimų rezultatai ypač augančios ekonomikos šalių atveju yra nepakankami ir prieštaringi.

\section{Bendrosios konkuravimo strategijos, eksporto marketingo strategijos ir jų poveikis ịmonès veiklos rezultatams}

Sąsajos tarp bendrujų konkuravimo strategijų, eksporto marketingo strategijų ir jų poveikio eksporto veiklos rezultatams moksliniuose darbuose mažai nagrinètos. Eksporto marketingo standartizacijos strategija rodo kiek eksportuojančios įmonès standartizuoja savo marketingo programą užsienio šalių rinkose, kitaip tariant, koks yra užsienio šalių rinkose taikomos marketingo programos panašumo lygis/laipsnis. Vienu kraštutiniu atveju eksportuojanti i̇monė gali plètoti visoms atskiroms užsienio šalių rinkoms skirtingas marketingo programas prekès, kainodaros, paskirstymo ir komunikacijos atžvilgiu, kitu kraštutiniu atveju imonė visoms eksporto rinkoms rengia ir igyvendina vieną marketingo programą.

Solberg ir Durrieu (2008) teigimu, dèl savo daugialypio pobūdžio strategijos koncepcija, kaip tyrimo objektas, yra labai sudètinga. Tarptautinio verslo kontekste išskiriami du strategiju lygmenys jų turinio atžvilgiu - bendrosios konkuravimo strategijos ir internacionalizavimo strategijos. Abu lygmenys gali igauti ivairias formas su savitomis dimensijomis. Tarptautinio (arba eksporto) marketingo strategijos priskiriamos prie funkcinių strategijų (Hagen, Zucchella, Cerchiello, Giovanni, 2011).

Solberg ir Durrieu (2008) teigimu, bendrosios konkuravimo strategijos i̇monès veiklos rezultatus veikia tiesiogiai ir netiesiogiai, tai yra bendruju konkuravimo strategiju poveikis imonès veiklos rezultatams yra moderuojamas ir kito tipo tarptautinių marketingo strategijų (autoriaus i̇vardijamų kaip strateginiu aljansu, persekiotojų, pasekejų, integracijos/veiklos metodų, standartizacijos ir pakopinès internacionalizacijos elgsenos). Empiriškai patvirtinta, kad bendrosios konkuravimo strategijos daro tam tikrą poveiki i̇monių internacionalizacijos elgsenai - nustatytas stiprus neigiamas koreliacinis ryšys tarp kaštų lyderystès strategijų ir nuosaikios tarptautinès plètros bei neigiamas ryšys tarp koncentracijos strategijų ir pasekejjų strategiju (Solberg ir Durrieu, 2006).

Kaštų lyderystė rodo, kad i̇monè pasiekė tam tikrų masto pranašumų, todėl tikètina, kad sieks pasinaudoti šiais pranašumais plèsdamasi i naujas rinkas, užimdama palyginti agresyvią poziciją internacionalizacijos atžvilgiu. Taigi, Solberg ir Durrieu (2008) daro prielaidą, kad pakopinè internacionalizacija turètų neigiamai koreliuoti su kaštų lyderyste. Taip pat autoriai mano, kaštų lyderystè susijusi su marketingo programos standartizacija. Atitinkamai, minèti autoriai kelia prielaidas, kad tarp kaštu lyderystès ir standartizacijos ryšys turètų būti teigiamas, o ryšys tarp kaštų lyderystès ir pakopinès internacionalizacijos - neigiamas.

Diferenciacijos strategiją taikančių i̇monių elgsena panaši, tačiau skatinama kitų motyvų. Šių ịmonių konkurencinio pranašumo šaltiniai - jų prekių ženklai arba prekès išskirtinumas. Diferenciacijos, kaip ir kaštų lyderystès atveju siekiama užimti didesnę rinkos dalį, nors ir taikant kitus marketingo taktinius sprendimus. Solberg ir Durrieu (2008) manymu, ryšys tarp diferenciacijos ir pakopinės internacionalizacijos taip pat turètų būti neigiamas. Koncentracijos strategijos rodo, kad įmonès savo veiklą yra sukoncentravusios i siaurą rinkos segmenta, siekdamos ji aptarnauti geriau nei jų didesni konkurentai. Ši tikslą imonèms pavyksta pasiekti igyjant pranašumą prekiu ir paslaugu arba kaštų atžvilgiu siaurame rinkos segmente. Laikui bėgant šios i̇monès tikètina išplètos specifinius konkurencinius pranašumus savo aptarnaujamuose rinkos segmentuose. Akivaizdu, kad dèl savo veiklos, orientuotos i siaurą rinkos segmentą, šios imonès paprastai yra mažos, taigi jų internacionalizacijos procesui užtikrinti būtina papildyti savo ribotus turimus išteklius plëtojant, pavyzdžiui, tinklinius santykius per strateginius aljansus (Solberg, Durrieu, 2008). Solberg ir Durrieu (2006) nustatè, kad koncentracijos strategijos yra susijusios su nuosaikesniu, pakopinès internacionalizacijos požiūriu tarptautinių rinkų atžvilgiu, argumentuodami, kad patrauklios nišos identifikavimas ir pozicijos joje stiprinimas tarptautinėse rinkose reikalauja daugiau laiko.

Solberg ir Durrieu (2008) manymu, bendruju konkuravimo strategiju tiesioginis ir netiesioginis poveikis i̇monès veiklos rezultatams ịvertinant ir kitų tarptautinių marketingo strategijų kontekstą turètu labiau paaiškinti skirtingus i̇monių veiklos rezultatus. Autorių manymu, platesnis strateginis požiūris ivertinant skirtingus strateginius lygmenis ir jų tarpusavio sąsajas sąlygoja gebejjimą subtiliau prisiderinti prie skirtingų rinkų poreikių ir iššūkių. Taigi, minètų autorių nuomone, įmonès veiklos rezultatus labiau paaiškina 
tiesioginis ir netiesioginis bendruju konkuravimo ir ivairių kitu tarptautiniu marketingo strategijų autorių ivardijamu internacionalizavimosi strategijomis, poveikis vienu metu nei kurios nors vienos šiu strategijų individualus poveikis.

Kaštų lyderystė tikètina yra svarus, reikšmingas akstinas taikyti iniciatyvias internacionalizacijos strategijas, šias prielaidas patvirtino Solberg ir Durrieu (2008) empirinis tyrimas. Tuo tarpu tarp diferenciacijos ir pakopinès internacionalizacijos elgsenos ryšys pasirodė esąs netiesioginis (isiterpiant koncentracijos ir kaštu lyderystès strategijoms). Diferenciacijos strategijos tik netiesiogiai neigiamai veikia pakopinę internacionalizacijos elgseną per kaštų lyderystės ir koncentracijos strategijas. Pažymètina, kad tiek bendrosios konkuravimo strategijos netiesiogiai per tarptautines marketingo strategijas, tiek tiesiogiai (kaštu lyderystès atveju) teigiamai veikia imonès veiklos rezultatus, tačiau netiesioginio ryšio atveju teigiamas poveikis tik nežymiai didesnis nei tiesioginio ryšio tarp bendrujų konkuravimo strategijų ir imonès veiklos rezultatų arba tarp tarptautinių marketingo strategijų ir i̇monès veiklos rezultatų atveju. Solberg ir Durrieu (2008) tyrimas taip pat atskleide koreliacini ryši tarp diferenciacijos ir kaštu lyderystès taip sudarant pagrindą kvestionuoti Porter (1980) argumentus dèl , „sstrigusių viduryje“ strategiju mažo veiksmingumo. Tuo tarpu autorių hipotezès dèl standartizacijos nepasitvirtino, tyrimo rezultatai parodè, kad standartizacija nesusijusi nei su bendrosiomis konkuravimo strategijomis, nei su pakopine internacionalizacijos elgsena, dar kartą patvirtinant standartizacijos konstrukto sudètingumą ir būtinybę analizuoti ịvertinant situacinių išorinių ir vidinių veiksnių, tokių kaip rinkos, pramonès šakos, ¿̇monès kompetencijų, marketingo sprendimų centralizacijos laipsnio poveiki.

Shilke ir Thomas (2009) teigimu, vis dar akivaizdūs vartotoju preferencijų skirtumai ịvairiose šalyse didina adaptacijos strategijos patrauklumą diferenciacijos strategiją taikančioms įmonèms. Imonès, kuriu konkurencinis pranašumas grindžiamas diferenciacija, paprastai disponuoja marketingo veiklai plètoti būtinomis kompetencijomis bei joms būdingas didesnis lankstumas, šioms imonėms savo pasiūlymus adaptuoti atskirų užsienio šalių rinkoms yra sąlyginai lengviau. Shilke ir Thomas (2009) manymu, šių imoniu veikla paprastai yra mažiau orientuota i masto ekonomijos tikslus, taigi diferencijuoti sprendimai šiuo atveju mažintu standartizacijos teigiamą poveiki imonès veiklos rezultatams. Kadangi standartizacijos požiūris diferenciacijos strategiją taikančiu i̇monių atveju yra mažiau patrauklus, tikètina kad diferenciacijos strategija mažina teigiamą standartizacijos poveiki imonès veiklos rezultatams. Minèti autoriai kelia prielaidą, kad diferenciacijos strategiją taikančiu imonių atveju teigiamas ryšys tarp standartizacijos ir imonès veiklos rezultatu yra silpnesnis nei šios strategijos netaikančių i̇monių atveju.

Alternatyvi kaštų lyderystès strategija susijusi su didesnėmis nei konkurentų pelno maržomis imanomomis dèl mažesnių gamybos, paskirstymo kaštų. Taigi, kaštų lyderystès strategiją plètojančios imonès gali pasinaudoti standartizacijos sąlygojamu kaštų taupymo potencialu. Zou ir Cavusgil (2002) taip pat pažymi, kad siekiant igyti konkurencini pranašumą grindžiamą žemais kaštais, optimalia globalaus marketingo strategija laikytina ta, kuomet parduodami standartizuoti produktai taikant standartizuotas marketingo programas. Kadangi standartizacijos dẻka galima pasiekti masto ekonomiją ir padidinti marketingo veiksmų efektyvumą ši strategija traktuotina kaip reikšmingas įtakos įmonès veiklos rezultatams veiksnys toms i̇monėms, kurios siekia apsisaugoti nuo konkurencijos išlaikydamos kaštu lyderystės poziciją. Taigi, autoriu požiūriu, kaštų lyderystès verslo strategija turi teigiamą moderuojanti poveikị standartizacijos ir įmonès veiklos rezultatų ryšiui. Taigi, keliama prielaida, kad kaštų lyderystės strategiją plètojančiu imonių atveju teigiamas ryšys tarp standartizacijos ir imonès veiklos rezultatų yra stipresnis nei šios strategijos netaikančių imonių atveju. Šie autoriai remdamiesi kontingencijos teorija analizuoja kaip ivvairių organizacinių veiksnių, tarp jų ir bendrujų konkuravimo strategijų įtakoje keičiasi standartizacijos teigiamo poveikio imonès veiklos rezultatams intensyvumas. Shilke ir Thomas (2009) manymu, pagrindinè diferenciacijos prielaida - išsiskirti iš konkurentu gali prieštarauti esminei standartizacijos prielaidai - taikyti tuos pačius marketingo komplekso elementus įvairiose tarptautinèse rinkose. Teoriniame lygmenyje imonė gali akcentuoti prekès diferenciaciją ir skirtingose užsienio šalių rinkose taikyti standartizuotas marketingo programas. Vis tik, kadangi rinkos konkurencinė struktūra arba rinkos pasiūla gali žymiai skirtis įvairiose rinkose, standartizacijos strategijos taikymas visose užsienio šalių rinkose galimai susilpnintų diferenciacijos sąlygotą konkurencini pranašumą. Taigi, siekiant išlaikyti diferenciacijos strategijos integralumą, nestandartizuotas marketingo požiūris laikytinas priimtinesniu. Nors minètų autorių prielaidos diferenciacijos strategijos atžvilgiu nepasitvirtino, jų teigimu labiau įtikinamus minèto ryšio rezultatus galėtu užtikrinti kontroliuojančiojo rinkos, rinkos struktūros kintamojo ịvertinimas. Ivertinus rinkos struktūrą diferenciacijos strategiją taikančios i̇monès galimai tiksliau nustatytu priimtiną standartizacijos i̇vairiose užsienio šalių rinkose lygi. Kaštu lyderystės strategijos atveju, autorių prielaidos pasitvirtino, empirinio 
tyrimo rezultatai atskleidè, kad i̇monès, kurių konkurencinė strategija grindžiama kaštu pranašumu, labiau geba pagerinti i̇monès veiklos rezultatus taikydamos standartizaciją. Shilke ir Thomas (2009) teigimu, tiek kaštų lyderystès, tiek marketingo programos standartizacijos tikslai sutampa - jie orientuoti $\mathfrak{i}$ didesni efektyvumą. Taigi, tarp kaštu lyderystès ir marketingo standartizacijos strategijų egzistuoja strateginis atitikimas, sinergijos potencialas.

Aulakh et al (2000) tyrè, kaip augančios ekonomikos šalių eksportuojančių įmonių taikomos kaštų lyderystės, diferenciacijos, marketingo standartizacijos bei geografinès diversifikacijos strategijos veikia šiu imonių eksporto veiklos rezultatus. Minèti autoriai analizavo, kaip skirtingos konkuravimo sąlygos išsivysčiusiose ir besivystančiose užsienio šalių rinkose, atsižvelgiant $\mathfrak{i}$ augančios ekonomikos šaliu imoniu ribotus vidinius išteklius, sąlygoja skirtingus kaštų lyderystès, diferenciacijos ir marketingo standartizacijos poveikius imoniu eksporto veiklos rezultatams. Svarbiausiais išorinės aplinkos veiksniais analizuojant augančios ekonomikos šalių imonių strateginius sprendimus, minèti autoriai ívardina konkurenciją ir aplinkos neapibrěžtumą, išreiškiamą dinamiškumo ir nestabilumo dimensijomis. Atitinkamai autoriai aplinkos poveikio ivertinimui pasitelkia eksporto rinkos krypties kintamaji, akcentuodami skirtingu strateginių sprendimų būtinybę eksportuojant ị išsivysčiusias šalis ir besivystančias šalis. Išsivysčiusių šaliu rinkos paprastai pasižymi intensyvesne konkurencija, jose veikia didesnis skaičius ištekliais turtingų imoniug, vartotojai šiose rinkose yra reiklesni, o pačios rinkos labiau dinamiškos dẻl dažnų pokyčiu vartotojų poreikiuose bei preferencijose, bei spartaus nauju prekių ir paslaugų ivedimo. Autorių nuomone, augančios ekonomikos šaliu įmonėms eksportuojant ị išsivysčiusių šalių rinkas, racionaliau taikyti kaštais grindžiamas strategijas, o eksportuojant i besivystančias šalis, kurių aplinka konkurencijos ir vartotojų elgsenos požiūriu yra panašesnè, diferenciacijos strategijos sąlygotu geresnius imoniu eksporto veiklos rezultatus. Šias prielaidas patvirtino autorių empirinis tyrimas. Kadangi augančios ekonomikos šalių i̇monès paprastai dèl ribotų išteklių koncentruojasi i brandos stadijoje esančias prekes bei neturi pakankamai lěšų vystyti prekès ženklus, kurie jei ir būtų plètojami išsivysčiusių šalių vartotojų paprastai ne itin palankiai vertinami, nes prekès iš besivystančių šaliu dažniausiai asocijuojasi su žema kaina ir kokybe, tokioms įmonès sudètinga konkuruoti pasitelkiant diferenciaciją. Eksportuojant iš besivystančios ekonomikos šalies i kitą besivystančios ekonomikos šali, Aulakh et al (2000) manymu, diferenciacijos strategija sąlygotu geresnius veiklos rezultatus nei kaštais grissta strategija. Augančios ekonomikos šaliu i̇monès neturi jokio kaštu pranašumo prieš kitas besivystančios ekonomikos šalių imones, taigi kaštais grindžiamos strategijos greičiausiai nebus veiksmingos besivystančiose rinkose. Tuo tarpu tyrimai rodo, kad besivystančių šalių vartotojai užsienietiškas prekes, nepriklausomai ar jos importuotos iš išsivysčiusių ar besivystančių šalių, vertina palankiai, suvokia kaip aukštesnès kokybės lyginant su šalies viduje pagamintomis prekèmis bei yra linkę mokèti premijines kainas. Pavyzdžiui, ankstyvosiose ekonominio perejjimo iš planinès i laisvają rinką stadijose vartotojai linkę pirkti užsienio prekes dèl jų naujumo, statuso, i̇domumo. Tačiau ekonomikai pereinant $\mathfrak{i}$ aukštesni išsivystymo lygmeni, didesni svorị pradeda igauti nacionaliniai elementai (Schuh, 1994). Aulakh et al (2000) nuomone, šis vartotoju palankumas leidžia diferencijuoti savo prekes pagal kilmès šalies dimensija, juolab, kad ir diferenciacijos strategijos igyvendinimas besivystančiose šalyse turètu būti susijęs su mažesniais kaštais nei išsivysčiusiose šalyse. Pažymėtina, kad autorių hipotezė, jog ryšys tarp augančios ekonomikos šalių imonių taikomų dvigubų konkuravimo strategijų ir jų eksporto veiklos rezultatų yra neigiamas, nepasitvirtino.

Mokslinėje literatūroje pažymima, kad standartizacijos strategija sietina su dviem požiūriais. Imonès gali perkelti savo vidaus šalies rinkoje išplètotas marketingo programas į kitas užsienio šalis. Toks požiūris pasiteisina stiprius prekių ženklus turinčių i̇monių atveju, kuomet juos palankiai vertina panašūs vartotojų segmentai skirtingose užsienio šalių rinkose. Kitu atveju, i̇monès kuria ir plètoja globalias prekes ir programas ịvertinant skirtingas vartotojų preferencijas įvairiose šalyse, atitinkamai daug investuodamos i tyrimus ir plètra, marketingo sprendimus.

Eksporto moksliniai tyrimai rodo, kad eksportuotojų atveju geresni eksporto veiklos rezultatai bus pasiekti adaptuojant marketingo komplekso elementus (Cavusgil, Zou, 1994) kadangi i rinką orientuoto požiūrio dèka gauta nauda viršija standartizacijos strategijos dèka sutaupytus kaštus. Tačiau šios prielaidos pasitvirtino tik prekès atveju. Aulakh et al (2000) nuomone, dèl augančios ekonomikos šalių i̇monių patirties trūkumo, šioms imonèms sudètingiau suformuoti heterogeniškas vartotojų preferencijas apjungianti standartizuotą pasiūlymą. Taip pat dèl mažesnès derèjimosi galios, adaptuotos atskiroms užsienio šaliu rinkoms marketingo strategijos būtų veiksmingesnès, ypač toks požiūris pasiteisintų pradiniame įmonių tarptautinès plètros etape. Taigi, Aulakh et al (2000) teigimu, augančios ekonomikos šalių eksportuojančiu imonių atveju tarp eksporto marketingo standartizacijos ir eksporto veiklos rezultatu ryšys bus neigiamas, bei 
neigiamas poveikis bus didesnis imonei eksportuojant $\mathfrak{i}$ išsivysčiusias šalis nei būtų eksportuojant i besivystančias, kur ekonominès ir infrastruktūros sąlygos yra panašios. Autorių empirinio tyrimo rezultatai šias prielaidas patvirtino tik iš dalies. I išsivysčiusias šalis eksportuojančių ir standartizuoto požiūrio besilaikančių imonių veiklos rezultatai yra prastesni, nei tų i̇monių, kurios savo marketingo programas adaptuoja. Tačiau rezultatai parodè, kad ryšys tarp standartizuotos eksporto marketingo strategijos ir imonès eksporto veiklos rezultatų eksportuojant ị tokias pat besivystančias šalis, nebuvo statistiškai reikšmingas.

Evans ir Mavondo (2008) teigimu, eksportuojant ị labiau psichologiškai nutolusias užsienio šaliu rinkas, prekès adaptacija eksporto šalies rinkoje imonèms gali būti nenaudinga, imonèms gali būti sunku konkuruoti su vietinemis i̇monėmis, kadangi tikètina, jog dèl adaptacijos įmonès praranda skirtingų verslo sąlygu konteksto nulemtą prekès unikalumą. Kita vertus adaptacijos šalininkai teigia, kad prekès adaptacija suteikia daugiau galimybių diferenciacijai eksporto rinkoje (Cavusgil, Zou, 1994), kas galiausiai sąlygoja geresnius įmonių veiklos rezultatus.

Bendrujų konkuravimo strategijų, eksporto marketingo strategijų ir jų poveikio imonių veiklos rezultatams empirinių tyrimų rezultatai apibendrinti 1 lentelèje.

1 lentelè. Ryšių tarp bendrujų konkuravimo strategijų, eksporto marketingo strategijų ir jų poveikio imonių veiklos rezultatams empirinių tyrimų rezultatai

\begin{tabular}{|c|c|c|}
\hline Autoriai & Teorinės prielaidos & $\begin{array}{l}\text { Empirinio tyrimo } \\
\text { rezultatai }\end{array}$ \\
\hline \multirow[t]{3}{*}{$\begin{array}{l}\text { Solberg ir Durrieu } \\
\text { (2008) }\end{array}$} & $\begin{array}{l}\text { Ryšys tarp kaštų lyderystės ir pakopinės internacionalizacijos } \\
\text { neigiamas }\end{array}$ & Pasitvirtino \\
\hline & $\begin{array}{l}\text { Ryšys tarp diferenciacijos ir pakopinès internacionalizacijos } \\
\text { neigiamas }\end{array}$ & Nepasitvirtino \\
\hline & Ryšys tarp kaštt̨ lyderystės ir standartizacijos teigiamas & Nepasitvirtino \\
\hline \multirow[t]{2}{*}{$\begin{array}{l}\text { Shilke ir Thomas } \\
\text { (2009) }\end{array}$} & $\begin{array}{l}\text { Teigiamą ryši tarp standartizacijos ir imonès veiklos rezultatu } \\
\text { sustiprina kaštų lyderystès strategija }\end{array}$ & Pasitvirtino \\
\hline & $\begin{array}{l}\text { Teigiamą ryši tarp adaptacijos ir imonès veiklos rezultatų } \\
\text { sustiprina diferenciacijos strategija }\end{array}$ & Nepasitvirtino \\
\hline \multirow[t]{4}{*}{$\begin{array}{l}\text { Aulakh, Kotabe ir } \\
\text { Teegen (2000) }\end{array}$} & $\begin{array}{l}\text { Iš besivystančiu šalių i išsivysčiusias: } \\
\text { Ryšys tarp kaštų lyderystès strategijos ir įmonès veiklos } \\
\text { rezultatu teigiamas }\end{array}$ & Pasitvirtino \\
\hline & $\begin{array}{l}\text { Iš besivystančių šaliu i besivystančias šalis: } \\
\text { Ryšys tarp diferenciacijos strategijos ir imonès veiklos rezultatu } \\
\text { teigiamas }\end{array}$ & Pasitvirtino \\
\hline & $\begin{array}{l}\text { Iš besivystančių šaliu i išsivysčiusias: } \\
\text { Ryšys tarp marketingo standartizacijos ir įmonės veiklos } \\
\text { rezultatų neigiamas }\end{array}$ & Pasitvirtino \\
\hline & $\begin{array}{l}\text { Neigiamas ryšys tarp marketingo standartizacijos ir eksporto } \\
\text { veiklos rezultatu yra stipresnis eksportuojant } \mathfrak{i} \text { išsivysčiusias } \\
\text { šalis nei } \mathfrak{i} \text { besivystančias }\end{array}$ & Pasitvirtino \\
\hline
\end{tabular}

Remiantis Aulakh et al (2000) teorinėmis prielaidomis, akivaizdu, kad augančios ekonomikos šalių įmonėms eksportuojant $\mathfrak{i}$ išsivysčiusias šalis geresnius eksporto veiklos rezultatus sąlygotų kaštu lyderystès strategijos ir eksporto marketingo strategijos adaptacija. Tačiau šios ižvalgos prieštarauja Shilke ir Thomas (2009) nuomonei, jog teigiamą marketingo standartizacijos poveiki imonès veiklos rezultatams sustiprina būtent kaštų lyderystès strategija. Bei prieštarauja pastarujų nuostatai, kad tarp bendruju konkuravimo strategijų ir tarptautinių marketingo strategijų (standartizacijos/adaptacijos) turètų būti suderinamumas. Kita vertus, kyla pagrịstų abejonių, kodèl augančios ekonomikos šaliu i̇monès negali turèti kaštais grindžiamo pranašumo prieš kitas augančios ekonomikos šalių imones, ir vienintele rekomenduotina konkuravimo strategija šių imonių atveju laikytina tik diferenciacija. Remiantis minètomis prielaidomis būtu galima manyti, kad augančios ekonomikos arba besivystančių šalių imonės turi tik vieninteli pasirinkimą diferenciacijos strategiją. Nes jeigu besivystančios šalies imonès konkurencinis pranašumas šalies vidaus rinkoje būtų grindžiamas kaštų pranašumu, tai kodèl eksportuojant i panašias ekonominio išsivystymo šalis, kur aplinka yra sąlyginai panaši, o konkurencija nedidelè, imonè negalètu taikyti tos pačios konkuravimo strategijos. Jei kaštų lyderystė pasiteisina vienoje rinkoje tai eksportuojant $\mathfrak{i}$ kitą, panašią, taip pat turètų pasiteisinti. 
Mokslinès literatūros analizė leidžia teigti, kad tik keletas mokslininkų analizavo empiriškai ir parodė ryšius tarp bendrujų konkuravimo strategijų, eksporto marketingo strategijos ir i̇monès veiklos rezultatų. Nors akivaizdu, kad tam tikrame kontekste bendrosios konkuravimo strategijos ir eksporto marketingo strategijos gali kartu veikti imonès veiklos rezultatus, dauguma teorinių ižvalgu yra prieštaringos ir stokoja akumuliuoto empirinio patvirtinimo.

\section{Naujos konceptualios eksporto marketingo strategijos, bendrųjų konkuravimo strategijų ir jų poveikio įmonès veiklos rezultatams įžvalgos}

Baldauf et al (2000) teigimu eksporto veiklos rezultatų determinantus galima suskirstyti $\mathfrak{i}$ išoriniu ir vidinių veiksnių grupes. Išoriniams i̇monès eksporto veiklos veiksniams priskirtini pramonès šaka, vidaus šalies ir užsienio šalies rinkos charakteristikos, vidiniams - vadybiniai veiksniai, imonès charakteristikos bei eksporto marketingo strategijos.

Eksporto marketingo strategija apima prekès, kainos, paskirstymo, logistikos ir rèmimo sprendimus, leidžiančius tinkamai reaguoti i užsienio šalių rinkų aplinkos jègas ir pasiekti i̇monès eksporto tikslus (Leonidou et al, 2002). Rengiant ir igyvendinant eksporto marketingo strategija pasitelkiami ivvairūs ištekliai ir gebejjimai, kurie, remiantis ištekliais grisstu požiūriu (angl. resource based view, RBV), traktuojami kaip esminè ilgalaikio konkurencinio pranašumo prielaida. Leonidou et al (2011) teigimu, eksporto kontekste, konkurencinis pranašumas atspindi, kaip sėkmingai imonè realizuoja savo marketingo strategiją. Tinkamas imonès eksporto marketingo strategijos igyvendinimas gali daryti poveiki tiek kaštais, tiek preke ar paslaugomis grindžiamam konkurenciniam pranašumui (Morgan, Kaleka, Katsikeas, 2004).

Mokslinèje literatūroje sutinkamos nuomonès, jog standartizacijos ir adaptacijos sprendimai turètu būti analizuojami i̇monès konkuravimo strategijos kontekste, įvertinant, koks būtu poveikis bendrai įmonès konkurencinei pozicijai, bei laikantis nuostatos, kad standartizacijos/adaptacijos strategijos pagrindinè grąža - tai ¿̨monès konkurencinis pranašumas (Albaum, Tse, 2001; Jain, 1989). Albaum ir Tse (2001) manymu, tarptautinès marketingo strategijos adaptacija turètų būti interpretuojama ne kaip siektinas rezultatas, bet kaip priemonè pasiekti aukštesniems įmonès tikslams, t.y. pasitelkiant standartizaciją ar adaptaciją užsienio šaliu rinkose ittvirtinti savo konkurencini pranašumą. Autorių empirinio tyrimo rezultatai patvirtino, jog nėra tiesioginio ryšio tarp adaptacijos strategijos ir i̇monès veiklos rezultatu, tačiau patvirtino egzistuojant ryši tarp adaptacijos ir konkurencinio pranašumo bei tarp konkurencinio pranašumo ir įmonès veiklos rezultatų. Morgan et al (2004) pažymi, kad eksporto kontekste labai svarbu analizuoti i̇monès gebejjimus pasiekti ir išsaugoti konkurencini pranašumą per efektyvų ir veiksmingą suplanuotos eksporto konkurencinès strategijos igyvendinimą. Tuo tarpu sprendimai susiję su klausimais ar adaptuoti ir kiek adaptuoti eksporto marketingo strategijas, priskirtini instrumentinèms strategijoms, padedančioms pasiekti pagrindini tikslą konkurencini pranašumą (Navaro, Losada, Ruzo, Diez, 2010). Kaip pavyzdžiui, adaptuojant marketingo programos elementus prie tarptautinès rinkos poreikių, lengviau diferencijuoti prekę bei didinti vartotoju lojalumą užtikrinant vartotojams didesnę vertę lyginant su konkurentais (Kaleka, 2002).

Hagen et al (2011) teigimu, aiški ir iniciatyvi strateginè orientacija imoniu internacionalizacijos kontekste bei šios orientacijos suderinamumas su verslo strategija sąlygoja geresnius imonès tarptautinès veiklos rezultatus. Hagen et al (2011) analizavo sąsajas tarp tarptautinèje rinkoje veikiančių įmonių strateginès orientacijos, strateginès elgsenos ir įmonių tarptautinès veiklos rezultatų. Minètų autorių teigimu, strateginès orientacijos sąlygoja išskirtines kompetencijas, kurios sudaro prielaidas inovacijoms, efektyvumui, kokybei ar adekvatesniam atsakui ị vartotojų poreikius, bei kiekviena iš šių kompetencijų gali būti panaudojama siekiant kaštu ar diferenciacijos pranašumo. Hagen et al (2011) tyrimas parodè, kad egzistuoja ryšys tarp diferenciacijos ir entrepreneriškų, i augimą orientuoto tipo imonių, taip pat atskleidžiant, kad šio tipo įmonès vienintelès akcentuoja marketingo adaptaciją užsienio šalių rinkose. Tuo tarpu kituose moksliniuose tyrimuose diferenciacija dažnai siejama su vartotojo ir rinkos orientacijomis. Nors mokslinèje literatūroje dar nèra aiškiu nuostatų dèl rinkos orientacijos ir tarptautinių marketingo strategijų (standartizacijos/adaptacijos) sąsajų, kadangi šis reiškinys tarptautinio verslo, eksporto marketingo kontekste tik neseniai pradètas analizuoti, sutinkama prielaidų, kad rinkos orientacijos atveju pirmenybė teikiama marketingo strategijos adaptacijai (Samiee, Chabowski, 2011). Taigi, apibendrinant ivvairiu autoriu ¡žvalgas, galima konstatuoti, kad diferenciaciją ir marketingo strategijos adaptaciją sieja rinkos orientacija, bei galima daryti prielaida, kad diferenciacijos strategiją taikančios įmonès labiau linkę adaptuoti savo eksporto marketingo strategijas.

Remiantis mokslinès literatūros analize, 1 paveiksle pateikiamas konceptualus bendrujų konkuravimo strategijų, eksporto marketingo strategijų ir i̇monès veiklos rezultatų sąsajų modelis. 


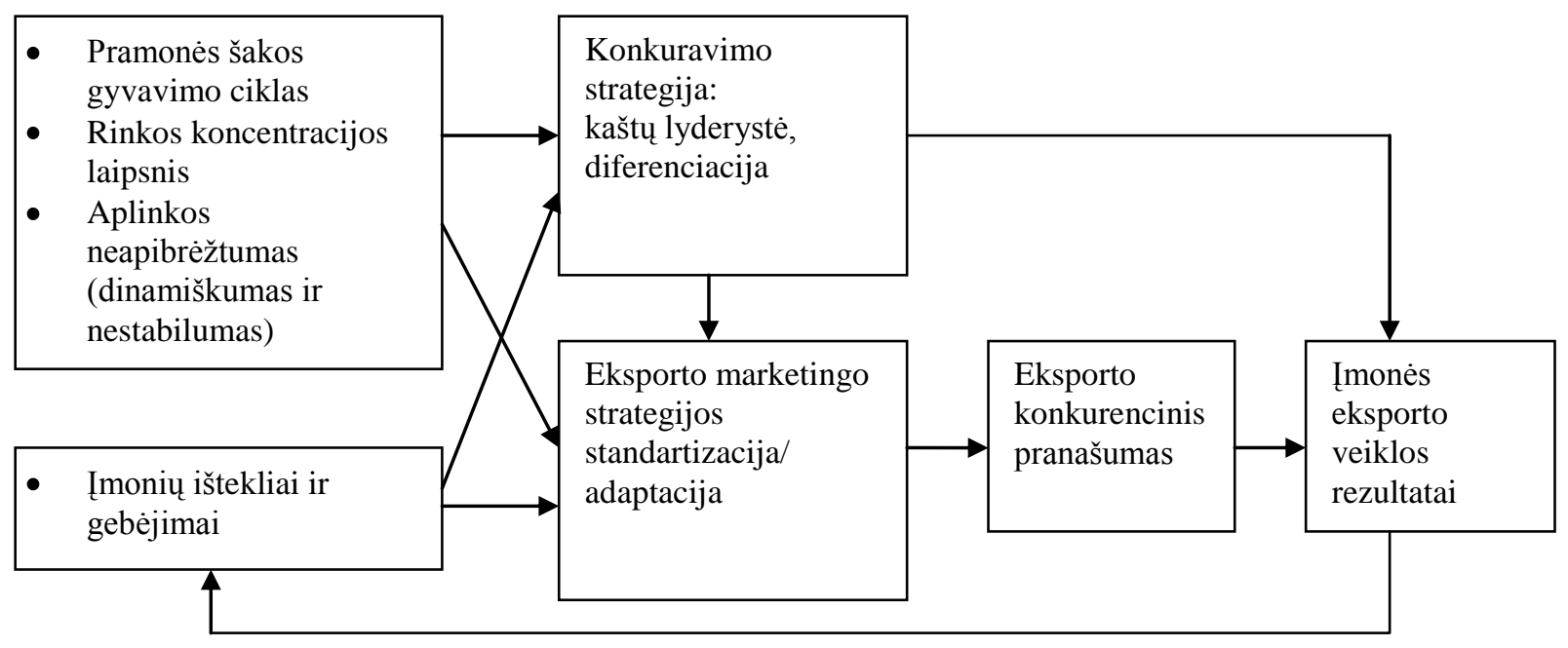

1 pav. Bendrujų konkuravimo strategijų, eksporto marketingo strategijos standartizacijos/adaptacijos ir eksporto veiklos rezultatų sąsajų konceptualus modelis

\section{Išvados}

Mokslinės literatūros analizė leidžia konstatuoti, kad tyrimai bendrujų konkuravimo strategijų bei eksporto marketingo strategiju poveikio eksporto veiklos rezultatams atžvilgiu yra fragmentiški, prieštaringi, tik keletas mokslininkų analizavo empiriškai ir parodė ryšius tarp bendrujų konkuravimo strategijų, eksporto marketingo strategijos standartizacijos/adaptacijos ir imonės veiklos rezultatų. Vieningo požiūrio i pagrindinių konstruktų teorinę konceptualizaciją stoka komplikuoja sąsajų tarp nagrinëjamų konstruktu analizę. Nors akivaizdu, kad tam tikrame kontekste bendrosios konkuravimo strategijos ir eksporto marketingo strategijos gali kartu veikti i̇monès veiklos rezultatus, dauguma teoriniu ižvalgų yra prieštaringos ir stokoja akumuliuoto empirinio patvirtinimo.

Naujausios mokslinès ižvalgos rodo, kad bendrujų pavienių ar dvigubų konkuravimo strategiju veiksmingumas jų poveikio įmonès veiklos rezultatams atžvilgiu priklauso nuo strategijų suderinamumo su ivairiais kontekstiniais veiksniais, kaip pavyzdžiui, pramonės šakos gyvavimo ciklo stadijos, rinkos neapibrèžtumo (dinamiškumo ir nestabilumo), rinkos koncentracijos laipsnio ar iejjimo į užsienio šalies rinką eiliškumo. Lankstūs strateginiai deriniai leidžia lengviau prisitaikyti prie dinamiškos globalios rinkos. Daugelio mokslininkų nuomone, kaštu lyderystès, diferenciacijos ar dvigubos strategijos efektyvumas turètu priklausyti nuo konteksto, aplinkos, kurioje šios strategijos igyvendinamos.

Vienu autorių (Shilke ir Thomas, 2009) požiūriu, kaštu lyderystès verslo strategija turi teigiamą moderuojantị poveikị standartizacijos ir imonès veiklos rezultatų ryšiui, o diferenciacijos strategija teigiamai veikia adaptacijos ir įmonès veiklos rezultatų ryši. Kitų autorių Solberg ir Durrieu (2008) nuomone, bendrujų konkuravimo strategiju tiesioginis ir netiesioginis poveikis imonès veiklos rezultatams, ivertinant ir kitu tarptautinių marketingo strategijų kontekstą, turètų labiau paaiškinti skirtingus imonių veiklos rezultatus. Bendrosios konkuravimo strategijos imonès veiklos rezultatus veikia per isiterpiančias tarptautines marketingo strategijas (standartizaciją/adaptaciją) ar imonių internacionalizacijos elgsenos būdingus modelius. Platesnis strateginis požiūris, ivvertinant skirtingus strateginius lygmenis ir jų tarpusavio sąsajas padètų suprasti reiškini daug giliau ir suteiktų papildomų ižvalgų.

Eksporto marketingo strategijos standartizacija/adaptacija turètu būti analizuojama imonès konkuravimo strategijos kontekste, ịvertinant, koks būtų poveikis bendrai įmonès konkurencinei pozicijai, eksporto marketingo strategija turètu būti interpretuojama ne kaip siektinas rezultatas, bet priemonè pasiekti aukštesnio lygmens i̇monès tikslus - pasitelkiant eksporto marketingo strategijos standartizacijąadaptaciją užsienio šalių rinkose įtvirtinti savo konkurencini pranašumą.

Apibendrinant ịvairių autoriu ižvalgas, galima konstatuoti, kad tiek diferenciaciją, tiek ir eksporto marketingo strategijos adaptaciją sieja rinkos orientacija, taigi galima daryti prielaidą, kad diferenciacijos strategiją taikančios įmonès labiau linkę adaptuoti savo eksporto marketingo strategijas. 


\section{Literatūra}

1. Albaum, G., \& Tse, D. K. (2001). Adaptation of International Marketing Strategy Components, Competitive Advantage, and Firm Performance: A Study of Hong Kong Exporters. Journal of International Marketing, 9(4), 5981.

2. Aulakh, P.S., Kotabe, M. \& Teegen, H. (2000), Export strategies and performance of firms from emerging economies: evidence from Brazil, Chile and Mexico, Academy of Management Journal, Vol. 43 No. 3, $342-61$.

3. Baldauf, Artur, David W Cravens, \& Udo Wagner. (2000). Examining Determinants of Export Performance in Small Open Economies. Journal of World Business, 35 (1): 61-79.

4. Beal, Reginald M. \& Masoud Yasai-Ardekani (2000), Performance Implications of Aligning CEO Functional Experiences with Competitive Strategies, Journal of Management, 26 (4), 733-62.

5. Buzell, R.D. and Gale, B.T. (1987), The PIMS Principle, Free Press, New York, NY.

6. Cavusgil, S.T. \& Zou, S. (1994), Marketing strategy-performance relationship: an investigation of the empirical link in export market ventures, Journal of Marketing, Vol. 58 No. 1, 1-21.

7. Chamberlin, E. H. (1933). The theory of monopolistic competition: A re-orientation of the theory of value. Cambridge, ME. Harward.

8. Coeurderoy, R. (2004). Leveraging the advantage of early entry: proprietary technologies versus cost leadership. Journal of Business Research, 57(6), 583-590.

9. Dess, G. \& Davis, P. (1984), Porter's (1980) generic strategies as determinants of strategic groups membership and organizational performance, Academy of Management Journal, Vol. 27 No. 3, 467-88.

10. Dumčiuvienè, D. (1999), Rinkos struktūros ir i̇monių elgsenos bei veiklos rodiklių sąveika: teorinis ivertinimas ir reikšmè ekonominei politikai. Daktaro disertacija. Kaunas, $21 \mathrm{p}$.

11. Durand R, Coeurderoy R. (2001). Age, order of entry, strategic orientation, and organizational performance. J Bus Venturing, 16:471-94.

12. Evans, J., Mavondo, F. T., \& Bridson, K. (2008). Psychic Distance: Antecedents, Retail Strategy Implications, and Performance Outcomes. Journal of International Marketing, 16(2), 32-63.

13. Grant R. Contemporary Strategy Analysis. Blackwell; 1998.

14. Hagen, B., Zucchella, A., Cerchiello, P., Giovanni, N. (2011). International strategy and performance - Clustering strategic types of SMEs. International Business Review, doi:10.1016/j.ibusrev.2011.04.002

15. Hall, William K. (1980), Survival Strategies in a Hostile Environment, Harvard Business Review, 58 (5), $75-85$.

16. Hill, Charles W.L. (1988), Differentiation Versus Low Cost or Differentiation and Low Cost: A Contingency Framework, Academy of Management Review, 13 (3), 401-412.

17. Hitt M, Ireland R, Hoskisson R. (2001), Strategic management: competitiveness and globalization. Mason: SouthWestern College Publishing.

18. Jain, S. C. (1989), Standardization of International Marketing Strategy: Some Research Hypotheses, Journal of Marketing, 53 (January), 70-79.

19. Jones, G.R. \& Butler, J.E. (1988), Revenue, and business level strategy, Academy of Management Review, Vol. 13 No. 2, 202-13.

20. Kaleka, A. (2002), Resources and Capabilities Driving Competitive Advantage in Export Markets: Guidelines for Industrial Exporters, Industrial Marketing Management, 31 (3), 273-83.

21. Leonidou, L. C., Palihawadana, D., \& Theodosiou, M. (2011). National Export-Promotion Programs as Drivers of Organizational Resources and Capabilities : Effects on Strategy, Journal of International Marketing, 19(2), 1-29.

22. Leonidou, Leonidas C. \& Saeed Samiee (2002), Marketing Strategy Determinants of Export Performance: A MetaAnalysis, Journal of Business Research, 55 (1), 51-67.

23. Li, C. B. \& Li, J. J. (2008). Achieving Superior Financial Performance in China: Differentiation, Cost Leadership, or Both? Journal of International Marketing, 16(3), 1-22.

24. Louri, Helen, \& V. Anagnostaki (1995), Entry in Greek Manufacturing Industry: Athens vs the Rest of Greece, Urban Studies, 32 (7), 1127-33.

25. Makadok R. (1999), Interfim differences in scale economies and the evolution of market shares. Strategic Management Journal; 20:935-52.

26. Miller, Danny (1988), Relating Porter's Business Strategies to Environment and Structure: Analysis and Performance Implications, Academy of Management Journal, 31 (2), 280-308.

27. Morgan, Neil A., Anna Kaleka, and Constantine S. Katsikeas (2004), Antecedents of Export Venture Performance: A Theoretical Model and Empirical Assessment, Journal of Marketing, 68 (January), 90-108. 
28. Mosakowski, E. (1993). A Resource-Based Perspective on the Dynamic Strategy-Performance Relationship: An Empirical Examination of the Focus and Differentiation Strategies in Entrepreneurial Firms. Journal of Management, 19(4), 819-839.

29. Murray, A.I. (1988), “'A contingency view of Porter's generic strategies, Academy of Management Review, Vol. 13 No. 3, 390-400.

30. Myers, Matthew B. \& Michael Harvey (2001), The Value of Pricing Control in Export Channels: A Governance Perspective, Journal of Inter- national Marketing, 9 (4), 1-29.

31. Navaro, A., Losada, F., Ruzo, E., Diez, J. (2010), Implications of perceived competitive advantage, adaptation of marketing tactics and export commitment on export performance. Journal of World Business, 45, 49-58.

32. O’Cass, A., \& Julian, C. (2003). Examining firm and environmental influences on export marketing mix strategy and export performance of Australian exporters. European Journal of Marketing, 37(3/4), 366-384.

33. Parker, Barbara \& Marilyn M. Helms (1992), Generic Strategic and Firm Performance in a Declining Industry, Management International Review, 32 (1), 23-39.

34. Parnell, J.A. \& Wright, P. (1993), Generic strategy: an empirical test of the miles and snow typology, British Journal of Management, Vol. 17 No. 2, 109-28.

35. Porter M. (1996). What is strategy. Harward Business Review. 61-78 [November- December].

36. Porter, M.E. (1980), Competitive Strategy: Techniques for Analyzing Industries and Competitors, The Free Press, New York, NY.

37. Porter, M.E. (1985) Competitive Advantage: Creating and Sustaining Superior Performance. New York: The Free Press.

38. Rust, Roland T., Christine Moorman, and Peter R. Dickson (2002), Getting Return on Quality: Revenue Expansion, Cost Reduction, or Both? Journal of Marketing, 66 (October), 7-24.

39. Samiee, S., \& Chabowski, B. R. (2011). Knowledge structure in international marketing: a multi-method bibliometric analysis. Journal of the Academy of Marketing Science, 40(2), 364-386.

40. Scherer, F.M. and David Ross (1990), Industrial Market Structure and Economic Performance. Boston: Houghton Mifflin.

41. Schilke, O., Reimann, M., \& Thomas, J. S. (2009). When Does International Marketing Standardization Matter to Firm Performance? Journal of International Marketing, 17(4), 24-46.

42. Schuh, A. (1994), Marketing in East Central Europe: an evolutionary framework for marketing strategy development, Conference on Marketing Strategies for Central and Eastern Europe, Vienna, Austria.

43. Solberg, C. A. (2006). Access to Networks and Commitment to Internationalisation as Precursors to Marketing Strategies in International. Networks, 46, December, 57-83.

44. Solberg, C. A., \& Durrieu, F. (2008). Strategy development in international markets: a two tier approach. International Marketing Review, 25(5), 520-543.

45. Ward, Peter T., Deborah J. Bickford, and G. Keong Leong (1996), Configurations of Manufacturing Strategy, Business Strategy, Environment and Structure," Journal of Management, 22 (4), 597-626.

46. Zou, Shaoming and S. Tamer Cavusgil (2002), The GMS: A Broad Conceptualization of Global Marketing Strategy and Its Effect on Firm Performance, Journal of Marketing, 66 (October), 40-56. 